\title{
Supply-side estimates of UK investment
}

\section{SUMMARY}

The UK is unusual among member countries of the Organisation for Economic Co-operation and Development in using business surveys on investment expenditure to estimate almost all nonresidential investment: a demand-side approach. More commonly, estimates of investment (or more precisely, gross fixed capital formation) are generated using available data on the supply of capital goods to the economy - a commodity flow model. This article describes how the commodity flow model can be used to form supply-side estimates of UK investment and discusses some of the advantages and disadvantages of this approach.
$\mathrm{N}$ ational Statistics Institutions (NSIs) around the world typically use three main approaches to measure gross fixed capital formation (GFCF):

- asking capital goods producers what they produced - many NSIs find this to be an efficient approach for collecting information on large and easily identifiable investment projects. Typically these include residential construction, factories and commercial buildings, roads, bridges, railways, and other large engineering works. Data collection is usually by means of surveys on construction activity. However, in the area of residential construction, administrative data sources can provide information on the number of starts or known time to completion. These volume indicators can then be supplemented with average unit costs, to generate investment series

- asking capital goods purchasers what they purchased - business surveys are administered to collect information on firms' capital expenditure. Despite being a direct and true expenditurebased approach, it is not common practice throughout the Organisation for Economic Co-operation and Development (OECD). The UK is in a minority by using this approach to calculate nearly all investment expenditure other than residential investment, and

- calculating the total supply of capital goods to the domestic economy - this is often referred to as a commodity flow model (CFM) estimate. CFMs are used by many NSIs to monitor and reconcile imbalances between the demand (expenditure) and supply (output) sides of the economy and are a useful tool in producing a single measure of gross domestic product (GDP). Because they relate the supply of commodities to the components of demand, such as GFCF, information on the former can then be used to construct estimates of the latter. This approach is implemented by the majority of OECD member countries to estimate expenditure on machinery and equipment

Various other methods are used for calculating specific parts of GFCF in the National Accounts. The most common is the use of registration documents for road transport equipment. Construction estimates are often based on indicators approximating the volume of work undertaken. These might include labour inputs, indices of construction output, and the supply of construction materials.

Table 1, which is reproduced from Table 6 in OECD (2001), summarises how these different methods are used for a number of OECD countries.

It is clear from Table 1 that supplyside methods dominate cross-country practices, whether this is directly through surveys of capital goods producers, or indirectly through a CFM. The demandside approach, by conducting (business) surveys on investment expenditure, is rarely used, with the UK a notable exception. This article investigates the impact of using a commodity flow method to produce estimates of GFCF for the UK. A number of possible advantages could result. 
Table 1

\section{OECD country practices in the measurement of gross fixed capital formation}

\begin{tabular}{|c|c|c|c|c|}
\hline Country & $\begin{array}{l}\text { Value/volume of work } \\
\text { done by capital goods } \\
\text { producers }\end{array}$ & $\begin{array}{l}\text { Capital outlays by } \\
\text { purchasers of capital } \\
\text { goods }\end{array}$ & Commodity flow/supply statistics & Other methods and description \\
\hline \multirow[t]{2}{*}{ Canada } & \multirow[t]{2}{*}{ Construction of dwellings } & \multirow[t]{2}{*}{-} & \multirow[t]{2}{*}{$\begin{array}{l}\text { Machinery and equipment other than } \\
\text { road transport equipment }\end{array}$} & $\begin{array}{l}\text { Construction other than dwellings: labour inputs in physical } \\
\text { terms and labour costs, materials supplied and material costs, } \\
\text { investment intentions, oil and gas drilling }\end{array}$ \\
\hline & & & & $\begin{array}{l}\text { Road transport equipment: estimated commercial share of } \\
\text { dealers' sales }\end{array}$ \\
\hline \multirow[t]{3}{*}{ United States } & \multirow{3}{*}{$\begin{array}{l}\text { Construction (dwellings } \\
\text { and other not elsewhere } \\
\text { specified) }\end{array}$} & \multirow[t]{3}{*}{ Improvements to dwellings } & \multirow[t]{3}{*}{$\begin{array}{l}\text { Appliances and home furnishings } \\
\text { Machinery and equipment }\end{array}$} & $\begin{array}{l}\text { Brokers' commissions on sale of new and existing dwellings: } \\
\text { numbers of units sold }\end{array}$ \\
\hline & & & & $\begin{array}{l}\text { Construction by non-communications utilities: trend } \\
\text { extrapolation }\end{array}$ \\
\hline & & & & Oil and gas well-drilling: footage drilled \\
\hline Japan & $\begin{array}{l}\text { Construction of dwellings, } \\
\text { public and unincorporated } \\
\text { sectors, other construction }\end{array}$ & $\begin{array}{l}\text { Corporate sector and other } \\
\text { construction; corporate sector } \\
\text { machinery and equipment }\end{array}$ & - & $\begin{array}{l}\text { Machinery and equipment not elsewhere specified: average } \\
\text { purchases by farms and unincorporated businesses with } \\
\text { estimated numbers of farms/unincorporated businesses }\end{array}$ \\
\hline Australia & $\begin{array}{l}\text { Construction (dwellings and } \\
\text { other) }\end{array}$ & $\begin{array}{l}\text { Transportation machinery and } \\
\text { equipment }\end{array}$ & Machinery and equipment & - \\
\hline New Zealand & $\begin{array}{l}\text { Construction of dwellings and } \\
\text { other buildings }\end{array}$ & Other construction & $\begin{array}{l}\text { Machinery and equipment other than } \\
\text { road transport equipment }\end{array}$ & Road transport equipment: registration records \\
\hline Austria & $\begin{array}{l}\text { Construction (dwellings and } \\
\text { other) }\end{array}$ & - & $\begin{array}{l}\text { Machinery and equipment other than } \\
\text { road transport equipment }\end{array}$ & Road transport equipment: registration records \\
\hline Denmark & Construction (private) & Construction (public) & $\begin{array}{l}\text { Machinery and equipment other than } \\
\text { road transport equipment }\end{array}$ & Road transport equipment: registration records \\
\hline \multirow[t]{3}{*}{ Finland } & \multirow[t]{3}{*}{-} & \multirow[t]{3}{*}{-} & \multirow{3}{*}{$\begin{array}{l}\text { Machinery and equipment other than } \\
\text { road transport equipment }\end{array}$} & Road transport equipment: registration records \\
\hline & & & & $\begin{array}{l}\text { Construction of dwellings and other buildings: index of } \\
\text { construction output }\end{array}$ \\
\hline & & & & Other construction: assumed to move in line with value added \\
\hline \multirow[t]{2}{*}{ France } & \multirow{2}{*}{$\begin{array}{l}\text { Construction of dwellings } \\
\text { (excluding dwellings not } \\
\text { sold and major repairs and } \\
\text { alterations to dwellings); } \\
\text { other construction }\end{array}$} & \multirow[t]{2}{*}{-} & \multirow{2}{*}{$\begin{array}{l}\text { Machinery and equipment other than } \\
\text { road transport equipment }\end{array}$} & Road transport equipment: registration records \\
\hline & & & & Major repairs and alterations to dwellings: trend extrapolation \\
\hline Germany & Construction & - & Machinery and equipment & - \\
\hline \multirow[t]{2}{*}{ Italy } & \multirow[t]{2}{*}{ Construction } & \multirow[t]{2}{*}{-} & \multirow{2}{*}{$\begin{array}{l}\text { Machinery and equipment not elsewhere } \\
\text { specified }\end{array}$} & Road transport equipment: registration records \\
\hline & & & & $\begin{array}{l}\text { Machinery and equipment produced by the primary, leather } \\
\text { goods and footwear industries: trend extrapolation }\end{array}$ \\
\hline Netherlands & - & Ships & $\begin{array}{l}\text { Machinery and equipment other than } \\
\text { ships }\end{array}$ & $\begin{array}{l}\text { Construction: productive hours worked and number of } \\
\text { employees in construction }\end{array}$ \\
\hline \multirow[t]{3}{*}{ Norway } & \multirow[t]{3}{*}{-} & \multirow{3}{*}{$\begin{array}{l}\text { Construction not elsewhere } \\
\text { specified, machinery not } \\
\text { elsewhere specified }\end{array}$} & \multirow[t]{3}{*}{ Ships } & Road transport equipment: registration records \\
\hline & & & & $\begin{array}{l}\text { Construction by non-transport and communication services: } \\
\text { buildings started }\end{array}$ \\
\hline & & & & $\begin{array}{l}\text { Machinery and equipment by non-transport and communication } \\
\text { services: assumed to move with gross output }\end{array}$ \\
\hline Spain & - & Construction & Machinery and equipment & - \\
\hline \multirow[t]{5}{*}{ Sweden } & \multirow{2}{*}{$\begin{array}{l}\text { Construction of dwellings } \\
\text { other than secondary } \\
\text { dwellings }\end{array}$} & \multirow[t]{5}{*}{-} & \multirow[t]{5}{*}{-} & \multirow{5}{*}{$\begin{array}{l}\text { Road transport equipment: registration records } \\
\text { Construction for agriculture: trend extrapolation } \\
\text { Land improvement for forestry: trend extrapolation } \\
\text { Secondary dwellings: trend extrapolation }\end{array}$} \\
\hline & & & & \\
\hline & $\begin{array}{l}\text { Construction other than } \\
\text { dwellings }\end{array}$ & & & \\
\hline & $\begin{array}{l}\text { Construction for agriculture } \\
\text { and forestry }\end{array}$ & & & \\
\hline & $\begin{array}{l}\text { Machinery and equipment } \\
\text { other than road transport } \\
\text { equipment }\end{array}$ & & & \\
\hline Switzerland & - & - & Machinery and equipment & $\begin{array}{l}\text { Construction: regression model using deliveries of construction } \\
\text { materials, employment in construction, etc. }\end{array}$ \\
\hline Turkey & Construction & - & Machinery and equipment & - \\
\hline United Kingdom & Construction of dwellings & $\begin{array}{l}\text { Construction other than } \\
\text { dwellings and for agriculture, } \\
\text { machinery and equipment }\end{array}$ & & Construction for agriculture: government investment grants \\
\hline
\end{tabular}


First, in the short run, more data are available in the UK for the output measure of GDP $(\mathrm{GDP}(\mathrm{O}))$ than for the expenditure measure (GDP(E)). Therefore, a CFM may deliver more timely estimates and, as Lynch and Caplan (1991) suggest, the approach could be particularly useful for picking up investment in parts of the economy where survey coverage is generally weak.

Second, there are gains in basing expenditure and output measures on the same sources. Resource cost savings result from not having to administer and process short-run (quarterly) investment surveys. Also, a CFM approach is convenient; it implicitly helps to balance the National Accounts because there is less difficultly in reconciling data on demand and supply in the economy.

Third and finally, concerns may exist over the capability of quarterly investment surveys to accurately capture companies' investment spending. Misreporting could occur because firms face difficultly in both recognising and recording their own expenditure. Firms may not fully understand how investment is defined in the National Accounts and are therefore unsure of which expenditure is current and which is capital. Measurement problems will also be more acute in the short run, due to limited information. For example, firms will typically have access to their full-year accounts when completing annual business surveys, but not to their quarterly ones.

The estimation of own-account software expenditure in the UK National Accounts offers a good example of the limitations of business surveys in recording capital expenditure (see Chamberlin, Clayton and Farooqui 2007 for more background). Once it was decided to classify software as a capital good in the 1993 System of National Accounts, it was obvious that there would have to be a consistent treatment of software that firms purchased and that produced in-house, known as own-account (after all, they are two means to the same end). While it was relatively easy to capture expenditure on purchased software, it was difficult to identify and value the resources used in the development of own-account software. Problems were compounded by the tax system offering encouragement to treat these outlays as current expenditure, creating a discrepancy between the treatment in company financial accounts and in the National Accounts. In telephone interviews of respondents to its quarterly investment inquiry, the Office for National Statistics (ONS) found that only 20 per cent of firms were correctly recording own-account software expenditure in their survey returns.
Despite these problems, the demandside approach offers some distinct advantages. A CFM measures capital expenditure indirectly so can only proxy the true target. Business investment surveys would provide an independent source of information and, even though this would require the reconciliation of alternative data sources, a more accurate description of investment trends might result. By directly asking firms about their investment expenditure, surveys may be more successful in picking up new shifts in activity. One of the main conclusions of this article is that the CFM approach relies heavily on fixed ratios that may well become outdated, leading to a structural bias in the results. For example, this appears to be the case where CFM-based investment measures are slow to pick up on fundamental shifts in investment, such as the ICT boom in the late 1990s.

\section{Commodity flow model}

The supply-side approach to estimating investment is a two-stage process. First, the total supply of goods and services is calculated using data on domestic output and imports. The second stage is to then allocate supply between the different components of demand, including GFCF.

The CFM is essentially a tool designed to analyse the imbalances between demand and supply data, that is, to reconcile the expenditure and output measures of GDP. Burnett (2001) gives a good description of how the model is used by ONS to assist in the quarterly balancing of GDP. However, it can easily be adapted to provide estimates of the demand side if there are complete data on the supply side and some knowledge of how supply is allocated between the demand components.

Central to the operation of the CFM are the annual input-output supply and use tables (SUTs) published by ONS. These show demand and supply data at a 123-industry and 123-product level of detail, as shown in Figure 1. In producing these tables, all the data are benchmarked to annual surveys and data from administrative sources, and fully balanced, resulting in uniform income, expenditure and output measures of GDP.

From Figure 1, the total supply of each of 123 products in current market prices for a particular year can be expressed as:

domestic output + imports + trade margins + net taxes $=$ total supply

The domestic output of each commodity can be calculated by extrapolating the latest figures in the SUTs with industry-output growth rates published by ONS in the Index of Production and GDP $(\mathrm{O})$ for the non-production sectors. Here, a simplified assumption is made to deal with the issue of one industry producing multiple products, that is, all the products produced by a certain industry are tied to the same growth rate. For example, the agricultural industry may generate an output of agricultural products and also tourist services but, in this framework, the domestic output of both products will grow at the same rate as the overall industry.

Import statistics of each of the 123 product groups can be deduced from the trade in goods and trade in services data. Trade margins and net taxes for each product are assumed at the same rate as in the most recent SUT.

Once the total supply of each product has been calculated, it is necessary to determine what proportion should be allocated to investment as opposed to the other components of demand. This is shown in the right-hand side of the SUT framework in Figure 1 where:

intermediate consumption + household consumption + non-profit institutions serving households + GFCF + valuables + inventories + exports $=$ total demand

Because export data are available from the same sources as import data, an estimate of this part of final demand can be produced and subtracted from total supply. The resulting problem is now one of allocating net domestic supply, which can be achieved by using the proportions in the latest SUT. Finally, an in-built spline function in the CFM allows the production of quarterly estimates based on annual SUT data.

The CFM approach based on extrapolating the most recent SUT data is prone to a number of problems. The most significant is that SUTs are produced with a lag of around two years, reflecting the timeliness of certain annual surveys and important administrative data such as that from HM Revenue \& Customs, as well as the time required to fully balance the three GDP measures. Therefore, if the economy undergoes an important structural change in this time, the ratios can become outdated and impart a bias on the results. A second consideration is that recent estimates of net domestic supply are generated using relatively new and unrevised output and trade data. Therefore, the CFM estimates of investment will not be immune to revision, and will be revised in line with the source data. 


\section{Figure 1}

\section{The input-output supply and use framework}

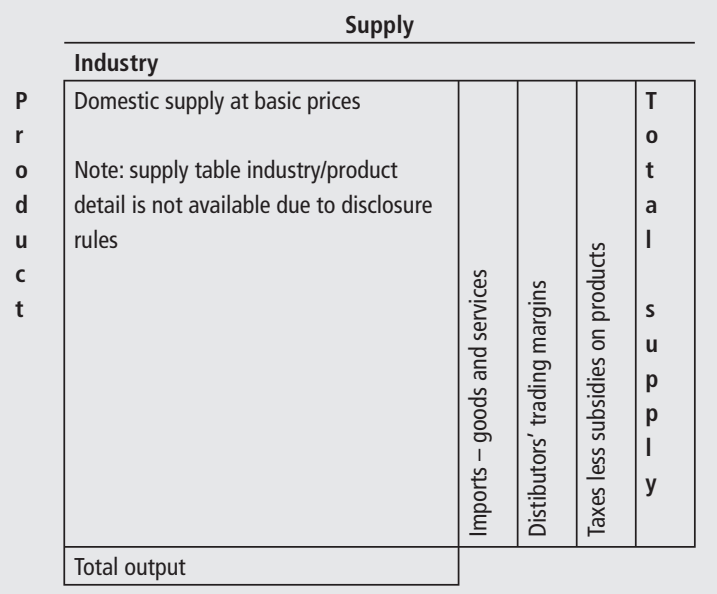

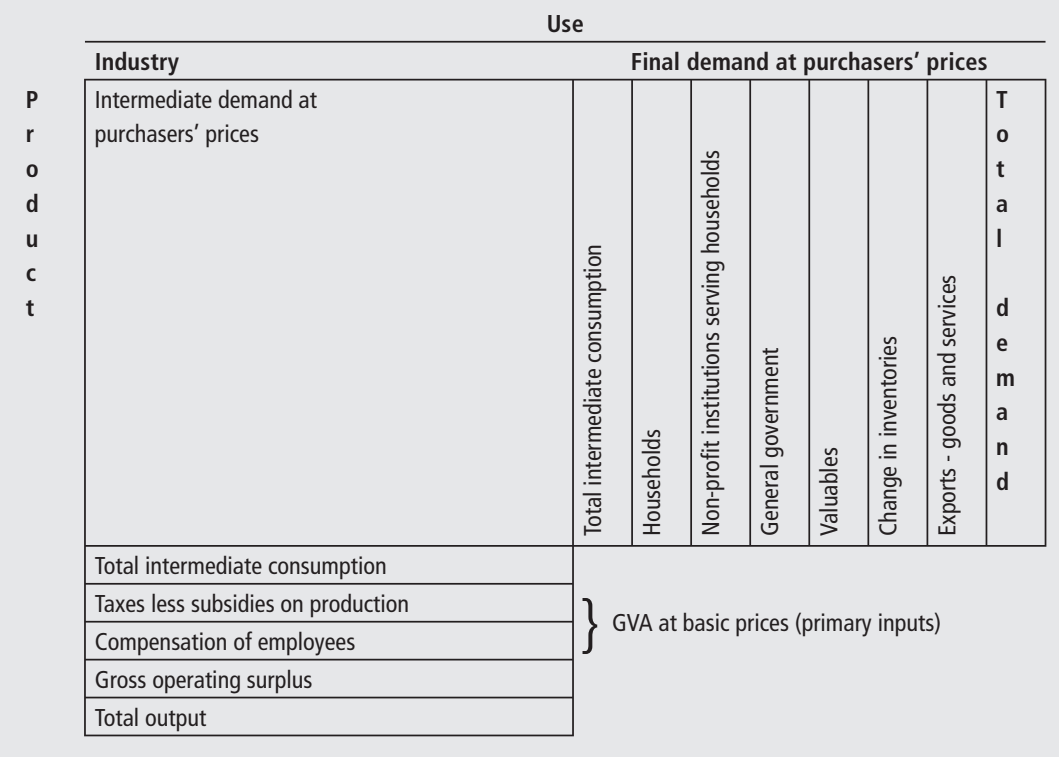

\section{Supply-side estimates of UK GFCF}

The latest SUTs were published in autumn 2006 and cover the period 1992 to 2004.

Hence, these data could be used to produce estimates of GFCF from 2006Q3 onwards. The results from the CFM estimates, along with the published data, are displayed in

\section{Figure 2}

Annual CFM estimates for 2004 should correspond with those published in the National Accounts. One thing to note here is that the published data have been adjusted to exclude the effects of the ownaccount software revision made in the reduced-scope Blue Book 2007 for which no corresponding SUTs were provided. The data have been backcast by four years to 2000 so as to provide sufficient observations for the spline function to work and provide a quarterly path of the data.

Estimates after 2004 reflect the workings of the CFM in extrapolating the net domestic supply of all 123 products and allocating by product to each component of demand, based on the SUT 2004 ratios. Of course, if this method were being used in real time, the first GFCF supply-side estimate would be 2006Q3. Estimates for 2005Q3 to 2006Q2 would need to come from extrapolating the 2003 SUT published in autumn 2005, and so on.

There are two noticeable features of the data. First, the CFM estimates tend to be relatively smooth compared with the published data. Second, the CFM estimates appear quite poor in that they badly underestimate the path of UK investment after 2004. Here, they are failing to pick up the strong rise in construction investment over the period.
This is also demonstrated in Figure 3, which plots the growth rates of the investment measures in Figure 2 along with the CFM estimate of total economy net supply (that is, all 123 products). Unsurprisingly, the growth rates of the CFM measure and that of total net supply are similar, but both are much less volatile than the published National Accounts investment series.

It seems that a general disadvantage of the CFM is that it fails to generate sufficient volatility in the investment data. It is not immediately obvious why this should be, since a large increase in the net supply of products largely classified as investment should be reflected in the estimates. It seems, therefore, that the fixed ratios implemented in the CFM may be to blame. In other words, the CFM applies a constant proportion of the total net supply of each product to GFCF, based on the ratio in the most recent SUT. Changes in this ratio over time, that is, the intensity of GFCF in total supply, would generate additional volatility.

Figure 4 plots the ratio of GFCF to total supply for the latest set of SUTs (1992 to 2004) published alongside Blue Book 2006. The ratio is not constant: there is an evident spike between 1998 and 2000 coinciding with a period of relatively strong investment growth in the UK economy. High investment growth rates at the end of the 1990s were the product of strong growth in the supply of certain products, coupled with an increased proportion represented by GFCF, particularly in construction, motor vehicles and office machinery products.

The pick-up in investment intensity of the construction, motor vehicles and office machinery products after 2001 was largely driven by construction and may account for the recent poor performance of CFM estimates in Figure 2. The whole economy ratio over this period, though, has remained fairly stable due to offsetting effects on the ratio from other machinery and software, where investment has grown at a slower rate than total supply.

Recursive CFM estimates are presented in Figure 5. Here, successive annual SUT data (1992 to 2003) are used to generate realtime investment estimates, with the results plotted against the published National Accounts figures. Clearly, the investment boom between 1998 and 1999 was not fully accounted for by the CFM approach, which would have been calculated using the ratios prevailing in the 1996 and 1997 SUTs. Looking at Figure 4, it is obvious that these ratios were too conservative. CFM estimates are then seen to jump in 2000 to 2001, as the 1997 ratios are replaced with the 1998 ratios. However, the CFM approach does seem to work reasonably well in the short run and where the ratio of GFCF to supply is relatively constant.

\section{Conclusion}

Using a CFM to derive estimates of investment is akin to forecasting, albeit using relevant information on the supply side of the economy as indicators. Hence these estimates are prone to the same problems encountered when forecasting, that is, structural changes in the economy that render the particular model obsolete. CFM-based estimates of investment do tend to work reasonably well over short periods of time when the economy is more stable. 


\section{Figure 2}

\section{Supply-side estimates of GFCF}

\section{$\mathrm{f}$ billion (2004 prices)}

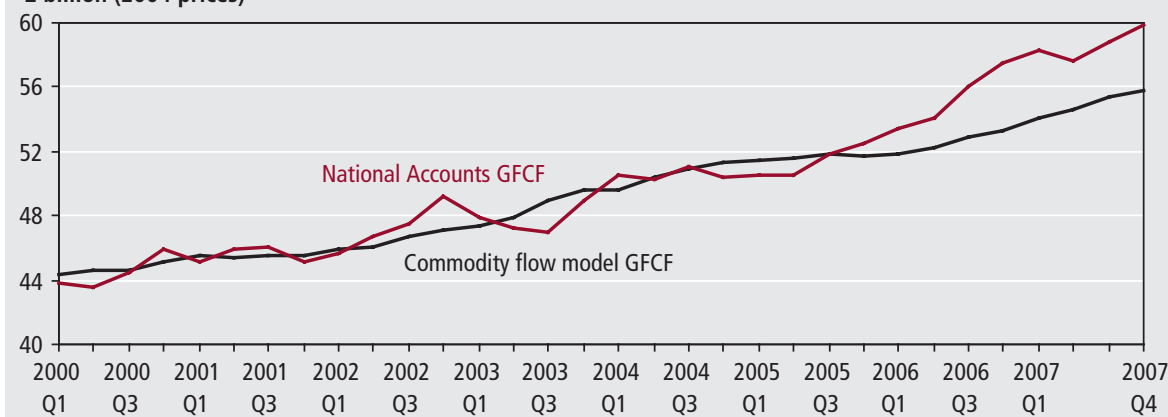

\section{Figure 3}

\section{GFCF growth rates}

Percentage change, quarter on same quarter a year earlier

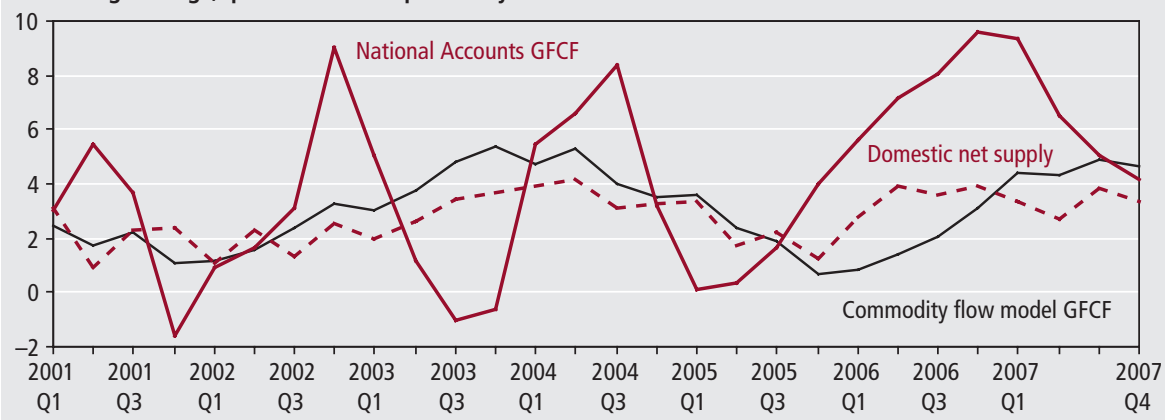

\section{Figure 4}

\section{GFCF as a proportion of total supply, as at Blue Book 2006}

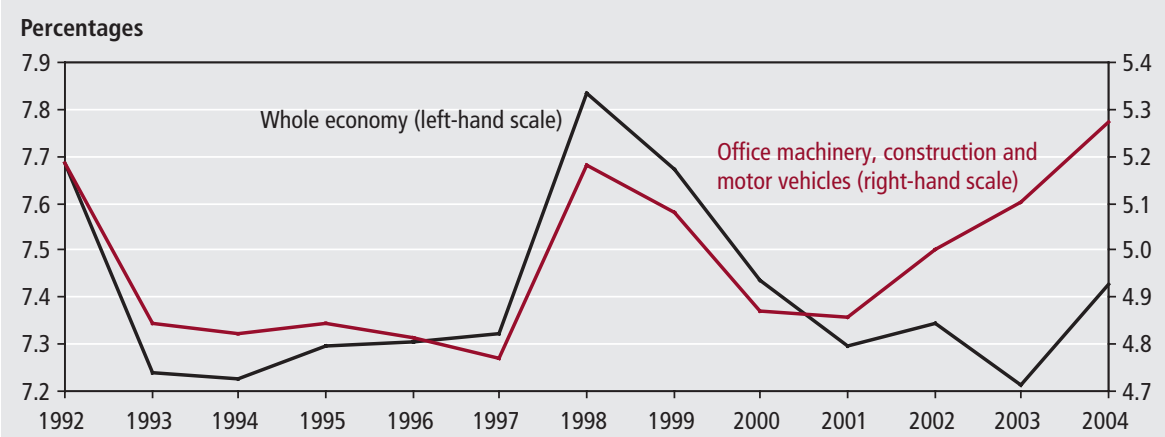

Figure 5

\section{Recursive CFM estimates}

$\mathrm{f}$ billion (2003 prices)

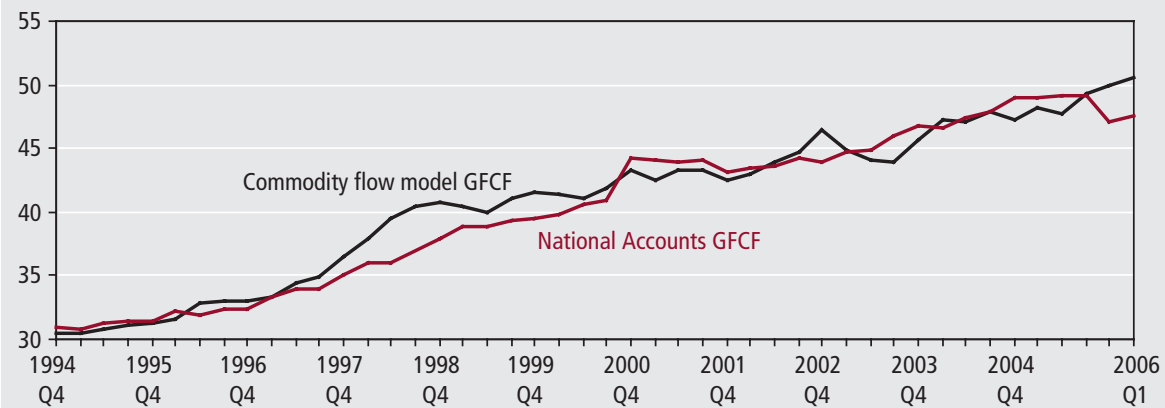

If net supply is allocated between intermediate and final demand on the basis of existing ratios, then CFM measures are prone to that ratio changing. For example, in the late 1990s, there was a large increase in the UK net supply of computers and other office machinery which was wholly accounted for by GFCF.
The process of allocating based on past ratios would see too much of that increase in net supply allocated to intermediate consumption or other parts of final demand. This demonstrates the potential importance of firm surveys, whether they are asking capital goods producers what they produced or capital goods purchasers what they purchased, as an alternative and independent source of information.

A potentially useful refinement of the CFM is to use information on the other components of demand to improve the measure of investment. For example, if ONS were reasonably confident about the quality of its household consumption and government spending data, it could subtract this as well as exports from estimates of total supply. So, if it were found that the total net supply of certain products grew at a faster rate, but that there was no corresponding pick up in household or government demand, then it would implicitly suggest that investment was also growing at a faster rate. The disadvantage of this approach is that investment estimates tend to become a residual, that is, the part of total supply not already accounted for by other factors. As a result, any errors in the estimates of these components of demand will feed directly into investment estimates.

In conclusion, it should be noted that the CFM gives a relatively timely and detailed product breakdown of investment expenditure and is particularly useful where the coverage of conventional business surveys is weak. Given the problems often encountered with short-term (quarterly) investment surveys, the CFM could still be useful as an indicator of investment trends.

\section{CONTACT}

هelmr@ons.gsi.gov.uk

\section{REFERENCES}

Burnett M (2001) 'Commodity flow analysis in quarterly balancing of GDP', Economic Trends 566, pp 33-7.

Chamberlin G, Clayton T and Farooqui S (2007) 'New measures of UK private sector software investment', Economic \& Labour Market Review 1(5), pp 17-28.

Lynch R and Caplan D (1991) 'The use of supply-side estimates in the national accounts', Economic Trends 458, pp 93-7.

OECD (2001) 'Quarterly National Accounts: Sources and Methods Used by OECD Member Countries'. 